\title{
Metabolic and Homeostatic Changes in Seizures and Acquired Epilepsy-Mitochondria, Calcium Dynamics and Reactive Oxygen Species
}

\author{
Stjepana Kovac ${ }^{1, *}$, Albena T. Dinkova Kostova ${ }^{2,3}$, Alexander M. Herrmann ${ }^{1}$ (D), Nico Melzer ${ }^{1}$, \\ Sven G. Meuth ${ }^{1}$ and Ali Gorji $1,4,5,6,7$ \\ 1 Department of Neurology, University of Münster, 48149 Münster, Germany; \\ alexander.herrmann@ukmuenster.de (A.M.H.); nico.melzer@ukmuenster.de (N.M.); \\ sven.meuth@ukmuenster.de (S.G.M.); gorjial@uni-muenster.de (A.G.) \\ 2 Division of Cancer Research, School of Medicine, Jacqui Wood Cancer Centre, Ninewells Hospital and \\ Medical School, University of Dundee, Dundee DD1 9SY, UK; A.DinkovaKostova@dundee.ac.uk \\ 3 Departments of Medicine and Pharmacology and Molecular Sciences, \\ Johns Hopkins University School of Medicine, Baltimore, MD 21205, USA \\ 4 Shefa Neuroscience Research Center, Khatam Alanbia Hospital, Tehran 1996836111, Iran \\ 5 Department of Neuroscience, Mashhad University of Medical Sciences, Mashhad 9177948564, Iran \\ 6 Department of Neurosurgery, University of Münster, 48149 Münster, Germany \\ 7 Epilepsy Research Center, University of Münster, 48149 Münster, Germany \\ * Correspondence: stjepana.kovac@ukmuenster.de; Tel.: +49-251-834-8189
}

Received: 13 August 2017; Accepted: 5 September 2017; Published: 8 September 2017

\begin{abstract}
Acquired epilepsies can arise as a consequence of brain injury and result in unprovoked seizures that emerge after a latent period of epileptogenesis. These epilepsies pose a major challenge to clinicians as they are present in the majority of patients seen in a common outpatient epilepsy clinic and are prone to pharmacoresistance, highlighting an unmet need for new treatment strategies. Metabolic and homeostatic changes are closely linked to seizures and epilepsy, although, surprisingly, no potential treatment targets to date have been translated into clinical practice. We summarize here the current knowledge about metabolic and homeostatic changes in seizures and acquired epilepsy, maintaining a particular focus on mitochondria, calcium dynamics, reactive oxygen species and key regulators of cellular metabolism such as the Nrf2 pathway. Finally, we highlight research gaps that will need to be addressed in the future which may help to translate these findings into clinical practice.
\end{abstract}

Keywords: epilepsy; reactive oxygen species; mitochondria; Nrf2; calcium; cell death

\section{Introduction}

Epilepsy, a devastating disease, affects over 50 million people worldwide [1] and is defined by the occurrence of unprovoked seizures. Most of these epilepsies are acquired as a consequence of a brain injury and are followed by a latent period of epileptogenesis [2]. Once unprovoked seizures occur, the patient is diagnosed with epilepsy and anticonvulsive treatment is initiated. Many patients become seizure free with antiepileptic drugs, although approximately one third of patients develop pharmacoresistant epilepsy [3], highlighting the unmet need for new treatment strategies. Current anticonvulsants mainly act on neuronal voltage gated ion channels, whereas downstream signaling cascades and non-neuronal cells are not targeted directly. However, the latter may be instrumental in mediating pharmacoresistance and also epilepsy comorbidities. It is likely that downstream signaling cascades such as metabolic and homeostatic cellular mechanisms contribute 
to epileptogenesis, fully established epilepsy and pharmacoresistant epilepsy, although the precise mechanisms remain unclear.

There are clinical hints pointing to a strong involvement of mitochondria and bioenergetics in epileptogenesis, seizures and epilepsy. For example, patients with mitochondrial mutations often present with epilepsy as a phenotypic manifestation of the disease [4], highlighting the involvement of mitochondrial dysfunction in epileptogenesis. In addition, seizure activity and epilepsy have been linked to energy failure, which has been hypothesized to lead to neuronal injury responsible for the clinical sequelae associated with epilepsy patients. The brain, which makes up only $2 \%$ of the total bodyweight, contributes up to $20 \%$ to the resting whole body metabolism. This large metabolic turnover is mainly due to synaptic transmission $[5,6]$ where vesicle cycling consumes the majority of presynaptic adenosine triphosphate (ATP) to mediate neuronal function [7]. Epileptiform activity also induces large ionic conductances and depletes vesicular stores. Restoration of these changes, i.e., restoration of cellular homeostasis, is an energy demanding process [8]. Thus, it is not surprising that ATP demand and production during seizures, epilepsy and particularly prolonged seizures, such as those seen in status epilepticus, the maximum expression of epilepsy, is critical. It should be noted though that mitochondria are not the only source of dysfunction in epileptic seizures, and there are also other targets of homeostatic imbalances that occur during seizure activity. The most prominent homeostatic changes during seizure activity include the accumulation of intracellular calcium and the increased production of reactive oxygen species (ROS). Neuronal compromise during seizure activity is dependent on intracellular $\mathrm{Ca}^{2+}$ entry [9]. There is accumulating evidence that $\mathrm{N}$-methyl-D-aspartate (NMDA) receptors play a pivotal role in intracellular $\mathrm{Ca}^{2+}$ accumulation during seizure activity. This is supported by robust evidence showing that blocking of NMDA receptor activity abolishes cell death both in vitro and in vivo [10-12]. NMDA receptor opening has also been shown to promote ROS production via nicotinamide adenine dinucleotide phosphate (NADPH) oxidase, an enzyme which has recently been drawn into the spotlight of seizure induced neuronal damage and neuronal autophagy $[13,14]$. Excess $\mathrm{ROS}$ and $\mathrm{Ca}^{2+}$ are potent triggers of the mitochondrial permeability transition pore opening, which is a key event and point of no return leading to mitochondrial swelling and cytochrome c release from mitochondria, subsequently triggering the cell death cascade [15-17].

In this review, we summarize current knowledge about metabolic and homeostatic changes in seizures and acquired epilepsy with a particular focus on mitochondria, $\mathrm{Ca}^{2+}$ dynamics, $\mathrm{ROS}$ and key regulators of cellular metabolism such as the nuclear factor erythroid 2-related factor 2 (Nrf2)pathway. It is not in the scope of this review to cover the extensive literature on genetic syndromes with mutations in genes coding for mitochondrial proteins or key enzymes of metabolism, which has been the subject of a number of other extensive reviews (e.g., $[4,18]$ ). Instead, we wish to focus on patients suffering from acquired epilepsies (e.g., such as epilepsy due to hippocampal sclerosis) who are frequently encountered in clinical practice and pose a challenge to practitioners given that $30 \%$ present with pharmacoresistant seizures [3,19]. Finally, we highlight research gaps that will need to be addressed in the future which may help to translate findings into clinical practice.

References for this review were identified through searches of PubMed with combinations of the terms from keywords from the subsection titles (e.g., mitochondria) and "epilepsy" or "seizures" from 1950 until July 2017. In addition, manuscripts were also identified through searches of the authors' own files and from reference lists of the articles pointed out by the PubMed searches. Due to space restrictions, the final reference list was compiled from a selection of the articles identified which were prioritized according to their originality and their ability to fit into the narrative style of the current review.

\section{Mitochondria and Epilepsy-Adenosine Triphosphate (ATP), $\mathrm{Ca}^{2+}$ and Cell Death}

Mitochondria, initially coined bioblasts, were first described by Richard Altmann in 1890 and were recognized to function as elementary organisms within the cell [20]. A further advance in their functional characterization came through the introduction of new methods to study electron transport 
and metabolic states of the respiratory chain [21-24]. Peter Mitchell introduced the chemiosmotic hypothesis of oxidative phosphorylation in 1961, linking energy metabolism to hydrogen transport across the mitochondrial membrane [25]. Oxidative phosphorylation is the main source of ATP generation in neurons since they lack powerful enzymes for glycolytic ATP production such as those that are available in astrocytes [26].

The mitochondria are organelles that are amongst others essential in three different homeostatic mechanisms. Firstly, their most prominent and obvious function is ATP production. Secondly, they are involved in $\mathrm{Ca}^{2+}$ homeostasis through buffering of intracellular $\mathrm{Ca}^{2+}$, and thus have been referred to as the "hub of $\mathrm{Ca}^{2+}$ signaling" [27]. Lastly, mitochondria are instrumental in apoptotic cell death amongst others through the release of intramitochondrial cytochrome c [28]. Links to seizures and epilepsy have been established for all three mechanisms.

\subsection{ATP during Seizures and Epilepsy}

Early pioneering experimental studies showed that glucose, ATP and other energetic substrates decrease during seizure activity, particularly if this is prolonged [29-31]. This has been confirmed on a cellular level, where ATP decrease during seizure activity has been shown in neurons [12]. Mitochondrial dysfunction and seizures have been closely linked to each other not only in epilepsies, i.e., mitochondrial epilepsies, but are also increasingly recognized as a target in acquired epilepsy [18]. Anaplerosis, a strategy that aims to restore mitochondrial function through providing tricarboxylic acid cycle substrates, has been recently advocated for use in acquired epilepsy [32]. The ketogenic diet, a high fat diet used for the treatment of epilepsies, has been shown amongst other effects to upregulate the neuronal expression of genes involved in the tricarboxylic acid cycle, oxidative phosphorylation and glycolysis, along with improving mitochondria complex activities and boosting mitochondrial biogenesis [33-36]. The ketogenic diet is particularly the treatment of choice in patients suffering from seizures due to glucose transporter 1 (GLUT-1) deficiency syndrome and pyruvate dehydrogenase complex deficiency, given that it circumvents the metabolic deficiencies in these syndromes [37]. However, the ketogenic diet has also been found to be an effective treatment in syndromes which are not directly linked to mutations in the metabolic pathway, such as Dravet syndrome or Doose syndrome $[37,38]$ and has been advocated for the treatment of epilepsies due to mitochonridal diseases [39]. The exact mechanisms of the seizure suppressive effect of the ketogenic remain elusive. Beside its anaplerotic properties and its effect on mitochondria, direct anti-seizure effects of ketone bodies, neurotransmitter and ion channel regulation as well as regulation of ROS amongst others have been shown to play a role [36].

\subsection{Mitochondria and $\mathrm{Ca}^{2+}$ Buffering in Seizures and Epilepsy}

Besides ATP production, the most important function of mitochondria is the buffering of excess $\mathrm{Ca}^{2+}$. Excess $\mathrm{Ca}^{2+}$ entry into neurons has been observed in rats that underwent status epilepticus induced by bicuculline and L-allylglycine [9]. In these studies, mitochondrial $\mathrm{Ca}^{2+}$ overload has been shown to lead to cell death and was particularly pronounced in CA1 and CA3 regions, which are areas of the central nervous system (CNS) that are very susceptible to seizure induced cell death $[9,40]$. It is interesting that these very early studies already identified mitochondria as the main site of $\mathrm{Ca}^{2+}$ accumulation during prolonged seizures.

Different pathways for mitochondrial $\mathrm{Ca}^{2+}$ buffering have been described in the literature. The mitochondrial uniporter (MCU), whose structure has been unraveled only recently [41], is the main site of $\mathrm{Ca}^{2+}$ entry into the mitochondria and is thus instrumental in $\mathrm{Ca}^{2+}$ buffering during excess $\mathrm{Ca}^{2+}$ overload. The uptake and extrusion of $\mathrm{Ca}^{2+}$ in mitochondria is coupled to $\mathrm{H}^{+}$and $\mathrm{Na}^{+}$cycling that is maintained by the electron transport chain, which creates a potential gradient across the mitochondrial membrane $[27,42]$ (Figure 1). Within the mitochondrial membrane, $\mathrm{Ca}^{2+}$ precipitates to insoluble $\mathrm{Ca}^{2+}$ phosphate complexes, a process which is dependent on the availability of phosphate. This in turn is also dependent on the proton gradient and thus more phosphate enters the mitochondria if the gradient 
is higher, i.e., when the mitochondria are hyperpolarized. $\mathrm{Ca}^{2+}$ homeostasis through the MCU has been shown to play a role during seizure activity. Inhibition of the MCU significantly attenuated neuronal death after pilocarpine-induced status epilepticus and reduced levels of intracellular ROS [43].

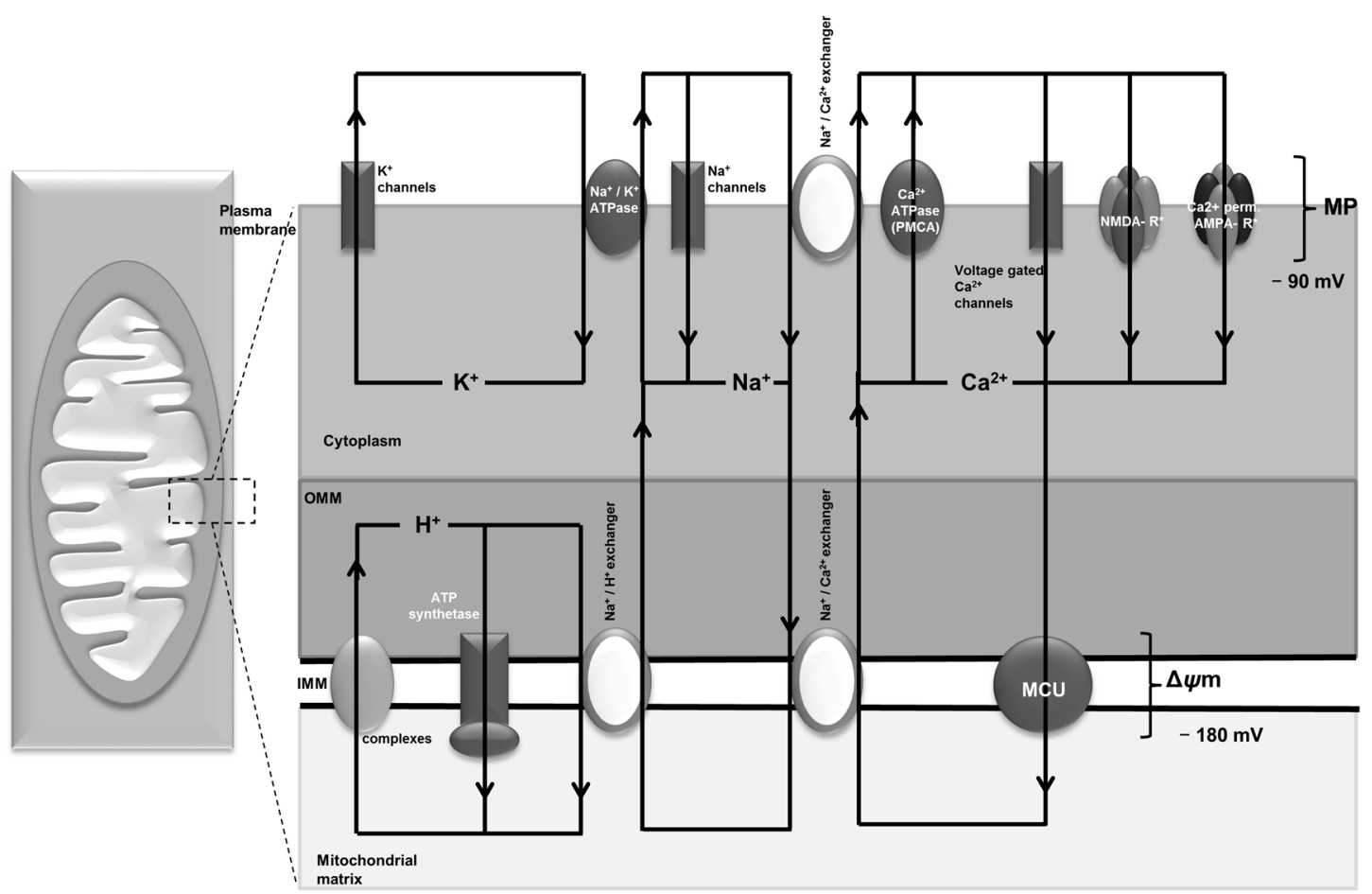

Figure 1. Ion circuits across mitochondrial and plasma membranes of a neuron. The figure shows a schematic drawing of ion circuits across mitochondrial and plasma membranes of a neuron. The respiratory chain is the driving force of these circuits either directly or indirectly by providing adenosine triphosphate (ATP) for all ATP-dependent processes [44]. MCU: mitochondrial $\mathrm{Ca}^{2+}$ uniporter; $\Delta \psi \mathrm{m}$ : mitochondrial membrane potential; MP: membrane potential; NMDA-R: $N$-methyl-D-aspartate receptor, AMPA-R: $\alpha$-amino-3-hydroxy-5-methyl-4-isoxazolepropionic acid receptor; OMM: outer mitochondrial membrane; IMM: inner mitochondrial membrane; PMCA: plasma membrane $\mathrm{Ca}^{2+}$ ATPase.

Mitochondrial permeability transition pore (MPTP) opening is another route for $\mathrm{Ca}^{2+}$ trafficking across the mitochondrial membrane (Figure 2). The MPTP is a protein complex in the inner mitochondrial membrane which has long been a mystery, but was recently found to be formed of two ATP synthase (Complex V) dimers [45,46]. The importance of MPTP opening was soon recognized in the triggering of apoptotic cell death through an increase in permeability of $\mathrm{Ca}^{2+}$ ions $[16,46]$. Our group has shown that seizure-induced cell death is partly mediated via MPTP opening as treatment with cyclosporine A, a potent inhibitor of MPTP opening, was able to reduce mitochondrial depolarization, the initial event leading to cell death during seizure activity [12]. More recently, an interesting link between the MPTP and epilepsy treatment was made. Ketone bodies, which are the main effectors of anti-seizure effects in the ketogenic diet and are a very effective anti-seizure treatment, have been shown to mediate anti-seizure effects via MPTP modulation [47]. In this study, mitochondria isolated from hippocampi of Kcna1-null mice with a genetic susceptibility to seizures had a higher threshold for $\mathrm{Ca}^{2+}$ induced mitochondrial permeability transition if they were pre-treated with ketone bodies. 


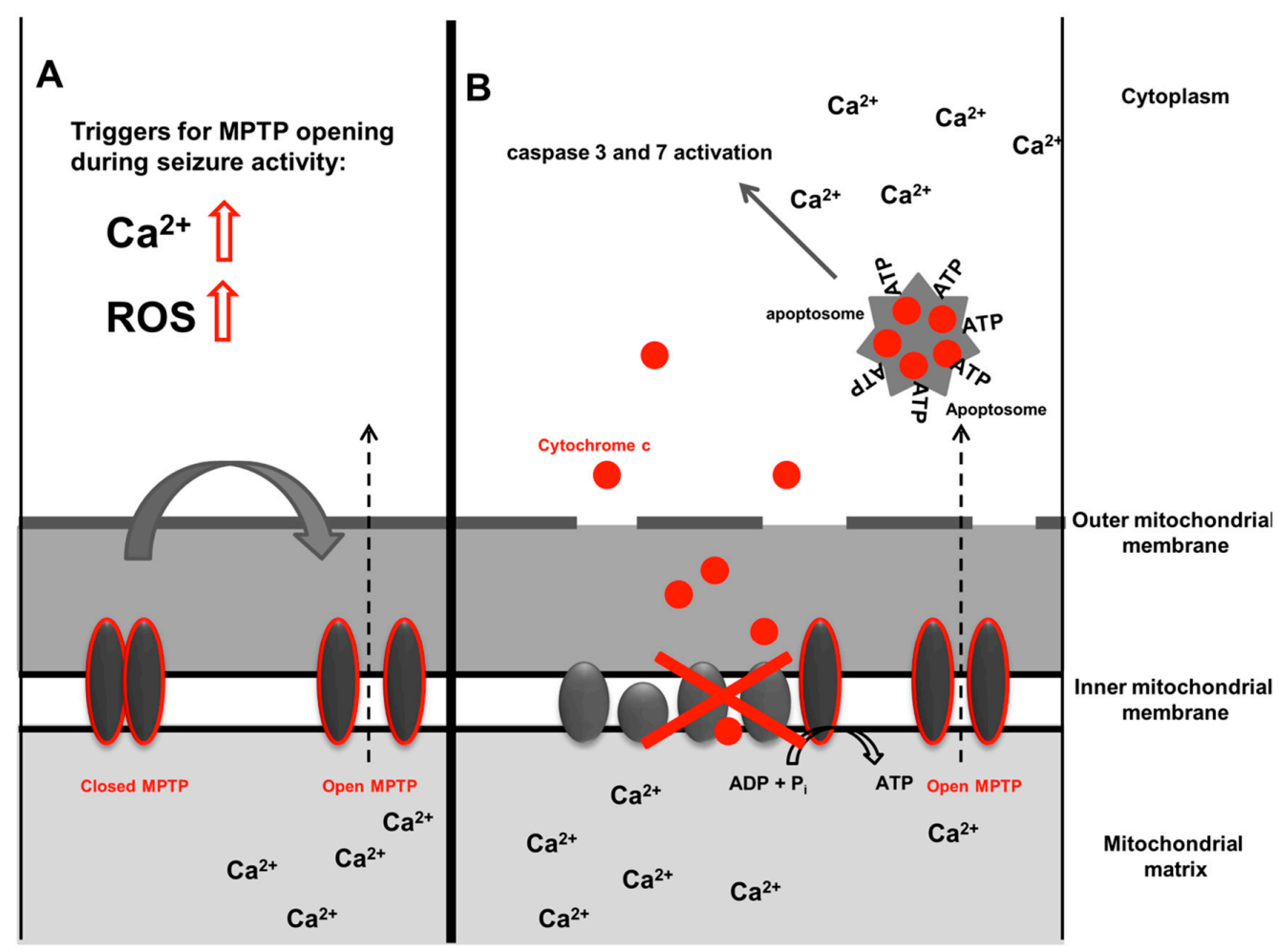

Figure 2. Mitochondrial permeability transition pore (MPTP) opening. Simplified model of the mitochondrial permeability transition pore. Permanent opening of the permeability transition pore leads to mitochondrial outer membrane permeabilization (MOMP). ADP: adenosine diphosphate; Pi: phosphate group; ROS: reactive oxygen species. Reduced function of the respiratory chain, as indicated with the red arrow (in B) subsequently leads to mitochondrial disintegration and release of cytochrome c.

\subsection{Cell Death, Mitochondria and Epilepsy}

Early pioneering experiments by Meldrum and colleagues in baboons showed that brain seizure activity can cause neuronal damage even in the absence of a systemic convulsion, showing that brain damage is not only a secondary phenomenon which occurs due to excessive muscle activation and subsequent lactate acidosis [48]. That seizure activity itself can cause neuronal injury is now widely accepted and it is appreciated that even non-convulsive status epilepticus can be a life threatening emergency that is often encountered in certain clinical settings such as the intensive care unit [49]. Mitochondria have now been put into the spotlight of seizure induced cell death. Continuous seizure activity leads to ATP depletion and subsequent cell death [12,50]. Excess $\mathrm{Ca}^{2+}$ accumulation results in mitochondrial swelling, permeability transition pore opening, activation of mitochondrial proteins that trigger cell death (Bcl-2 family proteins Bax and Bok proteins [51]), release of cytochrome c, activation of caspases which lead to mitochondrial permeability transition pore opening and loss of mitochondrial outer membrane integrity [16,52-56]. Abnormal mitochondrial distribution, altered mitochondrial motility, decreased mitochondrial membrane potential, and diminished mitochondrial respiration was observed in fibroblasts derived from two lethal encephalopathic patients with a loss of function TRAK1 (trafficking of kinesin proteins 1) variant that was also shown to be associated with seizures [57].

\section{Excess Intracellular $\mathrm{Ca}^{2+}$ during Seizure Activity-The Endoplasmic Reticulum}

Excess intracellular $\mathrm{Ca}^{2+}$ accumulation, which is one of the leading causes for seizure induced sequelae, is an event that is not only governed by the interplay of $\mathrm{Ca}^{2+}$ entry through the plasma membrane, but also by intracellular $\mathrm{Ca}^{2+}$ stores. An intracellular site of $\mathrm{Ca}^{2+}$ accumulation resides, 
as mentioned above, within the mitochondria. However, the endoplasmic reticulum (ER) has a larger capability to store intracellular $\mathrm{Ca}^{2+}$ and thus is pivotal in $\mathrm{Ca}^{2+}$ homeostasis.

The ER, which was first identified as the site for intracellular $\mathrm{Ca}^{2+}$ release for muscle contraction [58,59], was soon accepted to regulate $\mathrm{Ca}^{2+}$ homeostasis in cells other than muscle cells [60]. Inositol triphosphate (IP3) mediated mechanisms of $\mathrm{Ca}^{2+}$ release have been shown to play a role in many neurological diseases [61].

With regards to epilepsy, surprisingly very few studies have examined the role of ER $\mathrm{Ca}^{2+}$ stores. Preincubation of neuronal hippocampal cultures with thapsigargin, a drug that depletes intracellular ER Ca ${ }^{2+}$ stores, resulted in a decrease in the amount of neuronal excitation produced by bicuculline [62]. Ictal discharges induced by pilocarpine or (RS)-3,5-dihydroxyphenylglycine in hippocampal slices were dependent on internal $\mathrm{Ca}^{2+}$ stores as they were blocked by thapsigargin or dantrolene, which both affect $\mathrm{ER}-\mathrm{Ca}^{2+}$ stores [63]. A recent study showed that genetic silencing of nitric oxide-induced activation of the ryanodine receptor, a receptor triggering $\mathrm{Ca}^{2+}$ release from the ER, provides protection against cell death produced by kainate-induced status epilepticus [64]. This study highlights the importance of ER $\mathrm{Ca}^{2+}$ stores in mediating seizure-induced cell death.

In contrast to $\mathrm{Ca}^{2+}$ release from intracellular stores, extracellular $\mathrm{Ca}^{2+}$ entry has been identified as the most important route of $\mathrm{Ca}^{2+}$ entry during seizure activity, which is supported by a plethora of studies [11,12].

\section{4. $\mathrm{Ca}^{2+}$ Channels and Transporters in the Plasma Cell Membrane and Their Role in Epilepsy-NMDA Receptor, AMPA Receptor, VGCC and PMCA}

The NMDA receptor (NMDA-R) forms a heterotetramer comprising two GluN1 and two GluN2 subunits and is mainly permeable by $\mathrm{Na}^{+}$and $\mathrm{Ca}^{2+}$ ions. Depolarization of the cell opens the channel by dislodging $\mathrm{Mg}^{2+}$ and $\mathrm{Zn}^{2+}$ ions from the pore [65]. The NMDA receptor has been shown to be instrumental in seizure-induced neuronal death both in vitro [11,12] and in vivo [66,67]. The importance of NMDA receptors in epilepsy is underpinned by the fact that NMDA receptor hyperactivation and upregulation of NMDA regulatory subunits is found in focal cortical dysplasia, a highly epileptogenic lesion [68,69]. $\mathrm{Ca}^{2+}$ ions entering the cell upon NMDA receptor stimulation have been shown to be responsible for subsequent cell death promoted by NMDA receptor activation, since omission of $\mathrm{Ca}^{2+}$ ions from the extracellular solution mitigated the harmful NMDA receptor mediated effects [11].

However, clinical evidence points to a more complicated role of NMDA receptors in epilepsy. Antibodies against the extracellular N-terminal domain of the GluN1 subunit have been identified to be responsible for NMDA receptor encephalitis [70,71], an antibody mediated disease which commonly presents with seizures. It remains an unresolved paradox though, why reduction of surface NMDA receptors as seen in anti-NMDA-R encephalitis leads to seizures. In this context, it is interesting that, despite a dramatic clinical presentation of anti-NMDA-receptor encephalitis, including status epilepticus, only a paucity of inflammatory markers and neuronal cell death have been observed, which has repeatedly been confirmed in pathological brain specimens of affected patients [72-74].

Interestingly, mutations in subunits of the NMDA receptor, e.g., GRIN1 and GRIN2B, have recently been identified as a cause of epileptic encephalopathy presenting with seizures [75,76]. In addition, the $N R 1^{\text {neo/neo }}$ mouse model of NMDA receptor hypofunction showed a dramatic sensitivity to kainate induced seizures [77], highlighting the proconvulsant effect of NMDA receptor dysfunction. It has been suggested that NMDA hypofunction may play a role in neurotoxicity during seizure events [78].

Besides NMDA receptors, $\mathrm{Ca}^{2+}$ permeable AMPA receptors have been shown to play a role in status epilepticus [79]. How substantial their contribution is to $\mathrm{Ca}^{2+}$ mediated injury in seizures remains to be determined.

A review of the role of voltage gated $\mathrm{Ca}^{2+}$ channels (VGCC) channels is beyond the scope of this review. It should just be mentioned though that T-type and P/Q-type channels contribute to 
epileptogenesis, modulation of network activity, and genetic seizure susceptibility [80]. These channels have been linked to genetic forms of epilepsy and idiopathic epilepsy such as childhood absence epilepsy. Rodent genetic models of absence epilepsy have revealed that Cav3.1 and Cav3.2 T-type channel isoforms of VGCC are essential in the pathogenesis of absence epilepsy [81]. In addition, subsequently these channels have also been shown to play a role in acquired epilepsy [82,83].

While NMDA receptors, $\mathrm{Ca}^{2+}$ permeable AMPA receptors and voltage gated $\mathrm{Ca}^{2+}$ channels mediate the influx of $\mathrm{Ca}^{2+}$ into the cell, the plasma membrane ATPase (PMCA) together with the sodium $\mathrm{Ca}^{2+}$ exchanger (NCX) removes $\mathrm{Ca}^{2+}$ from the cell against its concentration gradient (Figure 1). A decrease of $\mathrm{Ca}^{2+}$-ATPase activities was found in pentylentetrazole treated rats [84]. The expression of the $\mathrm{Ca}^{2+}$ extrusion proteins (PMCA and NCX) has been studied in a rat model of kainate-induced status epilepticus [85]. This study found differences of PMCA and NCX isoform expression in neurons and astrocytes in hippocampal formation during epileptogenesis. Decreased PMCA expression levels have also been observed after status epilepticus [86]. The net effect on $\mathrm{Ca}^{2+}$ homeostasis in these regions during epileptogenesis, however, was not assessed in these studies.

\section{Epilepsy and Reactive Oxygen Species}

ROS contribute to neuronal damage in a wide range of neurological diseases [87-89], including seizures and epilepsy $[90,91]$. ROS include oxygen radicals such as superoxide, hydroxyl radicals, and hydrogen peroxide $\left(\mathrm{H}_{2} \mathrm{O}_{2}\right)$ molecules that are by-products of many biological reactions [92]. ROS in excess cause cellular damage due to oxidation induced protein dysfunction and oxidation of DNA and lipids. In an attempt to repair the cell's DNA, repair enzymes such as the poly(ADP-ribose) polymerase (PARP) excessively consumes ATP and thus stimulates cell death cascades through ATP depletion [93]. It is interesting in this context that PARP activation has recently been shown to contribute to status epilepticus induced mitochondrial function [94]. Whether ROS or sources of ROS are active in the upstream mechanisms of PARP activation has not been determined. ROS are also powerful enhancers of mitochondrial permeability transition pore opening. By stimulation of IP3/ryanodine receptors, sarco/endoplasmic reticulum $\mathrm{Ca}^{2+}$-ATPase pump inhibition and inhibition of plasma membrane $\mathrm{Ca}^{2+}$ channels, ROS increase intracellular $\mathrm{Ca}^{2+}$ levels, which together with ROS, then trigger mitochondrial permeability transition [46] (Figure 2). ROS can also directly interact with membrane lipids triggering lipid peroxidation. This process affects polyunsaturated lipids and increases the instability of the cell membrane [95]. The brain with its high content of polyunsaturated fatty acids is particularly prone to such damage [89].

There is overwhelming evidence supporting a role for ROS in epilepsy [96]. Early studies have investigated brain homogenates [97], whereas with advances in ROS imaging techniques, more sophisticated real time experiments could be performed allowing more detailed cellular analyses [13,98]. Despite this prominent role of ROS in cell homeostasis and in the triggering of mitochondrial dysfunction, previous results of antioxidant therapy in neurologic disease have been mixed. This is most likely due to a lack of characterization of the sources of free radical production and insight into mechanisms of antioxidant protection of the compounds used in these trials [99].

\subsection{Mitochondria and ROS in Seizures and Epilepsy}

Traditionally, mitochondria have been assumed to be the main site of ROS production during seizure activity. Some of this has been initially concluded by the coincidence of mitochondrial membrane depolarization, cellular ROS increases and cellular damage [98]. Complex III has been proposed to be a site of ROS production during seizures, which is based on findings from isolated mitochondria [90]. Using a mitochondria specific ROS probe, we were unable to demonstrate that ROS originate from the mitochondria during seizure like activity at least in the first few minutes of seizure activity [13]. Thus, the exact contribution of mitochondrial ROS to the overall ROS burden during seizures remains to be determined. 
A more recent study analyzed hippocampal and parahippocampal tissue samples from 74 patients with drug-refractory temporal lobe epilepsy and found that neuropathological signs of inflammation in patients suffering from hippocampal sclerosis correlated with mitochondrial DNA (mtDNA) mutations [100]. This finding supports the hypothesis that chronic inflammation leads to mitochondrial dysfunction by ROS-mediated mtDNA mutagenesis, which promotes epileptogenesis and neuronal cell loss in patients suffering from mesial temporal lobe epilepsy due to hippocampal sclerosis. This study is interesting since it draws attention to inflammatory ROS. In this model, mitochondria are the targets of ROS induced mutagenesis, with mitochondrial dysfunction occurring as a secondary effect.

\subsection{NADPH Oxidase Derived ROS and Epilepsy}

NADPH oxidase was discovered by studying the respiratory burst in phagocytes and granulocytes [101]. Subsequently, NADPH oxidase expression has been documented in many tissues. There is accumulating evidence highlighting the importance of NADPH oxidase, particularly the isoform NOX2 and NOX4, in brain disease $[13,102]$. In mammals, seven NADPH isoforms known as NOX1, NOX2, NOX3, NOX4, NOX5, dual oxidase (DUOX1) and DUOX2 have been documented [103,104]. NOX1, NOX2, NOX3 and NOX4 expression has been shown in neurons. NOX4 was demonstrated to play a major role in astrocytes, although NOX2 and NOX1 expression has also been documented [105]. Phagocytes were the cell type that fuelled the discovery of the NADPH oxidase [106]. Thus, besides neurons and astrocytes, microglia, the resident phagocytes of the CNS, unsurprisingly represent a prominent cell type that shows NADPH oxidase activity upon activation [107]. Oligodendrocytes are the only neural cells that do not express NADPH oxidase [104]. Amongst non-neural cells in brain tissue, endothelial cells or pericytes show high expression of NOX4 [108]. In fact, endothelial cells have been shown to be the main site of NOX4 expression [109].

NOX2 has been highlighted to play a role in seizures and epilepsy. This is not surprising since NMDA receptor activation, which has a leading role in epilepsy, has been found to trigger NOX2 assembly and activity [110,111]. We and others have found significant activation of NOX2 during seizure activity and suppression of this enzyme was effective in reducing seizure induced cell death in various epilepsy models [13,112-114]. Moreover, NOX2 seems to be involved in status epilepticus induced hypotension since NOX2 was found to be upregulated in the rostral ventrolateral medulla, a key nucleus of the baroreflex loop, which mediated status epilepticus-induced hypotension [115]. In addition, NADPH oxidase was also found to be involved in the vasogenic edema formation during status epilepticus [116]. Analyses of human tissue showed that NOX2 was upregulated in surgical hippocampal specimens from a patient suffering from pharmacoresistant seizures, highlighting that NADPH oxidase plays a role in acquired epilepsy [117]. Table 1 summarizes studies that have looked at the role of NADPH oxidase in epilepsy. It should be noted that some of the studies on the involvement of NADPH oxidase in epilepsy used non-subtype specific NADPH oxidase inhibitors such as apocynin and AEBSF (4-(2-aminoethyl)benzenesulfonyl fluoride hydrochloride) and thus, no conclusion on the isoforms of NADPH oxidase activation can be drawn $[14,118]$. In addition, there is a lack of studies on knock out animals, which would definitely add to the current evidence.

With regards to the other NADPH oxidase isoforms, besides NOX2, NOX4 has been highlighted as a major source of ROS in acute brain diseases such as stroke [102]. NOX4 is mainly located within intracellular organelles and produces superoxide that is rapidly dismutated into $\mathrm{H}_{2} \mathrm{O}_{2}$ [103]. We have previously shown that NOX2 produces ROS during seizure activity [13], yet NOX2 is particularly active in the early stages of seizure activity. It remains unclear whether other sources of ROS production are involved particularly in later stages of seizure activity, i.e., beyond the first few minutes. We have previously shown that energy depletion and impaired mitochondrial function occurs particularly in prolonged seizure activity [12]. In this context, NOX4-derived ROS are particularly interesting because of the interaction of NOX4 with mitochondrial function and its expression within mitochondrial membranes [119,120]. 
Table 1. Studies on the role of nicotinamide adenine dinucleotide phosphate (NADPH) oxidase in seizures and epilepsy.

\begin{tabular}{|c|c|c|c|c|c|}
\hline Study & Species & $\begin{array}{c}\text { Epilepsy Model } \\
\text { (In Vivo/Ex Vivo/In Vitro) }\end{array}$ & $\begin{array}{l}\text { NADPH Oxidase } \\
\text { Subtype Studied }\end{array}$ & NADPH Oxidase Inhibition & Main Findings \\
\hline $\begin{array}{l}\text { Zhu et al., } \\
2016[14]\end{array}$ & Mouse & $\begin{array}{l}\text { Pentylenetetrazol (PTZ) model } \\
\text { (in vivo) }\end{array}$ & No & $\begin{array}{l}\text { Pharmacological } \\
\text { (Apocynin) }\end{array}$ & $\begin{array}{l}\text { - Kindling induces NADPH dependent ROS production accompanied by mitochondrial } \\
\text { ultrastructural damage } \\
\text { - Pharmacological inhibition of NADPH oxidase by apocynin suppressed hippocampal } \\
\text { autophagy in the PTZ model }\end{array}$ \\
\hline $\begin{array}{l}\text { Williams et al., } \\
\text { 2015, [118] }\end{array}$ & Rat & $\begin{array}{l}\text { Perforant path stimulation (PPS) } \\
\text { model (ex vivo and in vivo) }\end{array}$ & No & $\begin{array}{l}\text { Pharmacological } \\
\text { (AEBSF) }\end{array}$ & $\begin{array}{l}\text { - } \quad \text { ROS are upregulated and glutathione levels are downregulated in chronic epilepsy } \\
\text { - ROS induced cell death in epilepsy can be blocked with NADPH oxidase inhibition } \\
\text { with AEBSF }\end{array}$ \\
\hline $\begin{array}{l}\text { Pecorelli et al., } \\
\text { 2015, [117] }\end{array}$ & Human & $\begin{array}{l}\text { Tissue from Patients with drug } \\
\text { resistant epilepsy (ex vivo) }\end{array}$ & Yes (NOX2) & $\mathrm{N} / \mathrm{A}$ & p47(phox) and p67(phox) (NOX2) expression in epileptic hippocampus \\
\hline $\begin{array}{l}\text { Kovac et al., } \\
2015 \text { [13] }\end{array}$ & Rat & Low magnesium model (in vitro) & Yes (NOX2) & $\begin{array}{l}\text { Pharmacological } \\
\text { (AEBSF, gp-91-tat) }\end{array}$ & $\begin{array}{l}\text { - } \quad \text { ROS were generated primarily by NADPH oxidase and later Xanthine oxidase } \\
\text { - } \quad \text { Inhibition of NADPH or xanthine oxidase reduced seizure-like activity-induced } \\
\text { neuronal apoptosis }\end{array}$ \\
\hline $\begin{array}{l}\text { Kim et al., } \\
\text { 2013, [116] }\end{array}$ & Rat & Pilocarpine induced SE (in vivo) & Yes (NOX2) & $\begin{array}{l}\text { Pharmacological } \\
\text { (Apocynin) }\end{array}$ & $\begin{array}{l}\text { - Vasogenic edema in SE is mediated via tumor necrosis factor- } \alpha \text { (TNF- } \alpha \text { ) stimulated } \\
\text { endothelin- } 1 \text { (ET-1) release and subsequent endothelial nitric oxide synthase and NADPH } \\
\text { oxidase activation } \\
\text { - Inhibition of NADPH oxidase attenuated SE induced vasogenic edema }\end{array}$ \\
\hline $\begin{array}{l}\text { Kim et al., } \\
\text { 2013, [112] }\end{array}$ & Rat & $\begin{array}{l}\text { Pilocarpine induced epilepsy (ex } \\
\text { vivo and in vivo) }\end{array}$ & Yes (NOX2) & $\begin{array}{l}\text { Pharmacological } \\
\text { (Apocynin) }\end{array}$ & $\begin{array}{l}\text { - Pilocarpine-induced seizure increased NOX2 expression in the plasma membrane of } \\
\text { hippocampal neurons at } 12 \mathrm{~h} \text { post-insult } \\
\text { - Apocynin treatment prevented this increase }\end{array}$ \\
\hline $\begin{array}{l}\text { Tsai et al., } \\
\text { 2012, [115] }\end{array}$ & Rat & $\begin{array}{l}\text { SE due to focal temporal injection } \\
\text { of kainic acid (TLSE; ex vivo and } \\
\text { in vivo) }\end{array}$ & Yes (NOX2) & $\begin{array}{l}\text { Pharmacological } \\
\text { (Apocynin) }\end{array}$ & $\begin{array}{l}\text { - } \quad \text { p47phox (NOX2) is upregulated in the rostral ventrolateral medulla, a key nucleus of the } \\
\text { baroreflex loop, which mediated SE induced hypotension } \\
\text { Pretreatment with apocynin by microinjection reduced baroreflex-mediated sympathetic } \\
\text { vasomotor tone in an experimental model of temporal lobe status epilepticus }\end{array}$ \\
\hline $\begin{array}{l}\text { Di Maio et al., } \\
\text { 2011, [114] }\end{array}$ & Rat & $\begin{array}{l}\text { Pilocarpine induced seizures } \\
\text { (in vitro and ex vivo) }\end{array}$ & Yes (NOX2) & $\begin{array}{l}\text { Pharmacological } \\
\text { (Apocynin, } \\
\text { 6-amino-nicotidamid) }\end{array}$ & $\begin{array}{l}\text { - } \quad \text { Apocynin and 6-aminonicotidamid were able to prevent thiol oxidation in vitro } \\
\text { - } \quad \text { p47phox (NOX2) redistribution to the neuronal cell membrane was seen after pilocarpine } \\
\text { treatment (ex vivo) }\end{array}$ \\
\hline $\begin{array}{l}\text { Pestana et al., } \\
\text { 2010, [91] }\end{array}$ & Rat & Pilocarpine induced SE (in vivo) & No & $\begin{array}{l}\text { Pharmacological } \\
\text { (Apocynin) }\end{array}$ & Apocynin inhibited ROS production and cell death in CA1 and CA3 areas \\
\hline $\begin{array}{l}\text { Patel et al., } \\
\text { 2005, [113] }\end{array}$ & Rat & Kainate model of epilepsy (ex vivo) & Yes (NOX2) & $\mathrm{N} / \mathrm{A}$ & $\begin{array}{l}\text { - Kainate-induced seizures result in the translocation of gp91phox (NOX2) and increased } \\
\text { NADPH-driven superoxide production in hippocampal membranes }\end{array}$ \\
\hline
\end{tabular}




\subsection{Other Sources of ROS in Epilepsy}

Other sources of ROS have been described in seizures and epilepsy, including xanthine oxidase, cyclooxygenase and lipoxygenase $[13,96,121,122]$. Xanthine oxidase, an enzyme involved in the catabolism of purines, may be an important source of ROS production during prolonged seizures since breakdown of ATP enhances xanthine oxidase activity. The exact contribution of these sources to ROS production during seizures and epilepsy remains unknown, but it is likely that they are not the main ROS producers in these conditions.

One strategy to decrease the ROS burden during seizure activity is to reduce ROS production by blocking key enzymes; another strategy is to boost ROS scavengers. With regards to the latter, the Nrf2 pathway represents an ideal target.

\section{Key Regulators of Energy Metabolism and ROS-A Focus on Nrf2 in Seizures and Epilepsy}

Nrf2 is a transcription factor that has been shown to regulate both antioxidant defense and intermediary metabolism and thus combines some of the mechanisms outlined above [123-126]. One of its main negative cytoplasmic regulators is Kelch-like ECH associated protein 1 (KEAP1). KEAP1 is responsible for ubiquitination and proteosomal degradation of Nrf2 and thus tightly controls its activity [127-129]. Nrf2 is a potential drug target and there are powerful small molecule inducers that activate Nrf2 by chemically modifying cysteine sensors of KEAP1 or disrupt KEAP1 binding [130-133]. Some of these small molecule Nrf2 inducers, such as RTA408, are currently being investigated in clinical trials for the treatment of mitochondrial myopathy and Friedreich's ataxia (Avaliable online: https: / / clinicaltrials.gov). Moreover, dimethyl fumarate, a drug licensed for use in multiple sclerosis, is an Nrf2 inducer [134], and thus this drug would lend itself to repurposing. Binding of these small molecules to KEAP1 leads to Nrf2 stabilization and translocation to the nucleus where it binds as a heterodimer with a small Maf transcription factor to the antioxidant response element, a specific DNA sequence in the promoter of Nrf2 target genes. This then stimulates transcription of antioxidant proteins such as glutathione-S-transferases (GSTs), NAD(P)H:quinone oxidoreductase 1 (NQO1) as well as enzymes involved in glutathione biosynthesis and regeneration $[135,136]$. Interestingly Nrf2 also controls mitochondrial function by enhancing substrate availability [124]. In addition, it has been reported that treatment of rats with the pharmacological Nrf2 activator sulforaphane promotes resistance of liver mitochondria to redox-regulated MPTP opening [137]. More recently, we have also highlighted an important interaction between NADPH oxidase expression and the Nrf2 pathway where different expression patterns of NOX4 were seen in neuronal cultures with constitutively active Nrf2 in comparison to Nrf2-knockout cells and controls [138]. All these mechanisms of action render $\mathrm{Nrf2}$ an attractive target to treat seizures.

Nrf2 has been highlighted as a target in the treatment of seizures and epilepsy [96,139]. One of the first descriptions of a protective effect of Nrf2 on seizures and epilepsy came from Mazzuferi and colleagues [140]. They screened biosets from epilepsy-related studies and identified Nrf2 as an important transcription factor in epilepsy. They then showed that Nrf2 mRNA expression is increased in human epileptic tissue and in murine brain tissue after status epilepticus. Adeno-associated virus mediated-overexpression of Nrf2 reduced the frequency and duration of seizures induced by pilocarpine in mice. Several studies with small molecule enhancers, i.e., Nrf2 inducers, have been performed. Daily injections of sulforaphane for five days elevated the seizure thresholds to $6 \mathrm{~Hz}$ stimulation and fluorothyl-induced seizures. In addition, it protected mice against pilocarpine-induced status epilepticus, demonstrating its efficacy in various epilepsy models [141]. Sulforaphane also suppressed the progression of amygdala kindling, and also ameliorated the cognitive impairment induced by epileptic seizure [142]. An interesting approach was chosen in a recent study by Pauletti and colleagues [143] where they combined the Nrf2 inducer sulforaphane with $\mathrm{N}$-acetylcysteine treatment with the rationale that these mechanisms are complementary in increasing glutathione levels, as glutathione is one of the main intracellular antioxidants and thus one of the most potent ROS scavengers within the brain. Sulforaphane at high doses $(>100 \mathrm{mg} / \mathrm{kg})$ was shown to lead to sedation, 
hypothermia, impairment of motor coordination, decrease in skeletal muscle strength, and deaths in addition to offsite effects such as leucopenia [144]. It should be noted, however, that such high concentrations are not necessary for Nrf2 activation and were not administered in the studies that showed a protective effect of sulforaphane. These studies largely used a dose of $5 \mathrm{mg} / \mathrm{kg}$. In addition, efforts are underway to develop highly potent blood-brain barrier permeable Nrf2 inducers and some of the currently available inducers as omaveloxolone (RTA408) have been developed in an attempt to increase blood-brain barrier permeability [145].

Figure 3 summarizes metabolic and homeostatic changes during seizures and epilepsy and the pathways that can be targeted to ameliorate these changes.

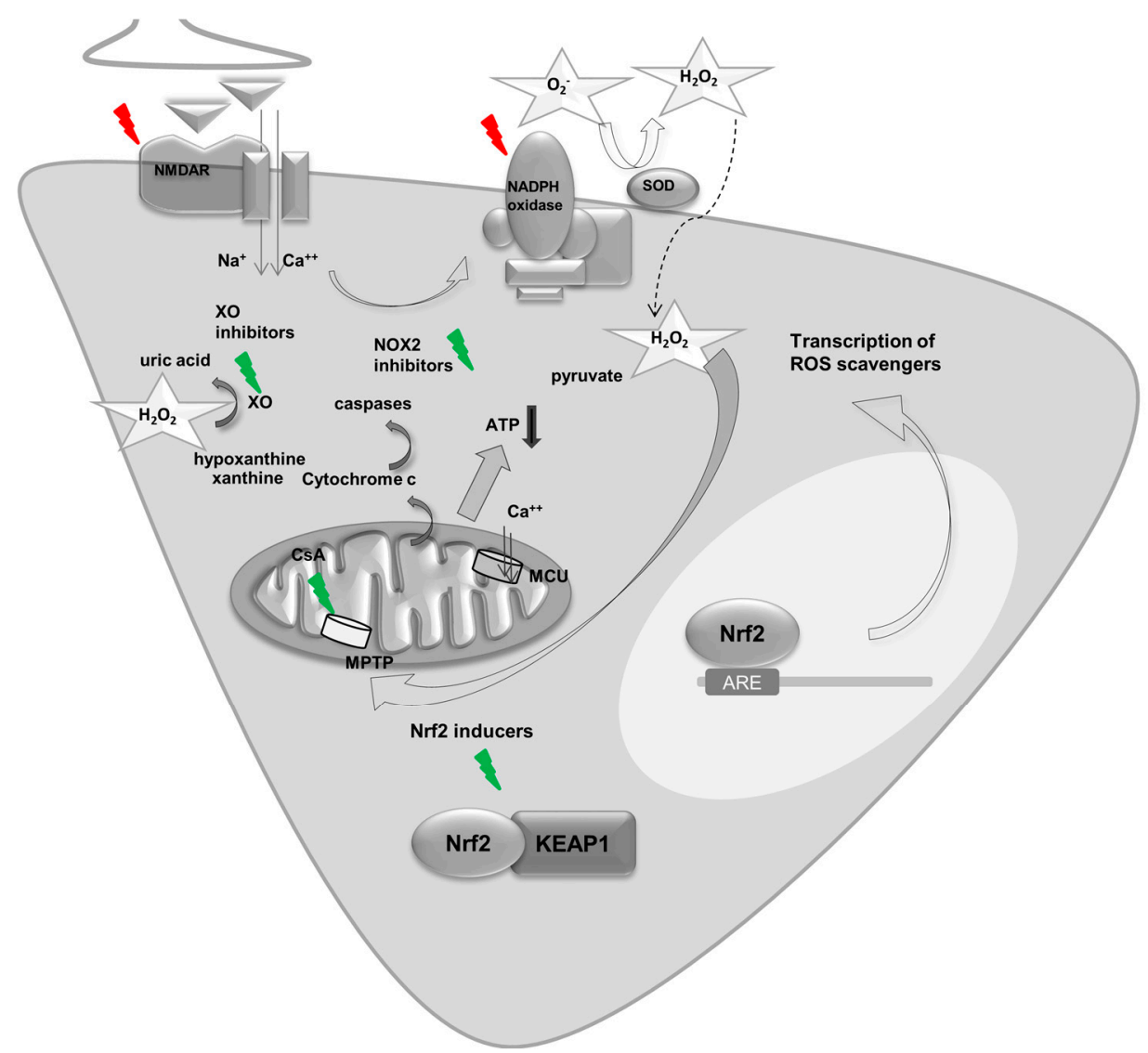

Figure 3. Metabolic and homeostatic changes during seizures and epilepsy. Metabolic and homeostatic changes during seizures and epilepsy and pathways that can be targeted to ameliorate these [96]; NMDA-R: NMDA-Receptor; SOD: superoxide dismutase; ARE: Antioxidant Response element; MCU: mitochondrial $\mathrm{Ca}^{2+}$ uniporter; MPTP: mitochondrial permeability transition pore, $\mathrm{O}_{2}{ }^{-}$: superoxide. KEAP1: Kelch-like ECH-associated protein 1; XO: xanthine oxidase. The red flashes indicate processes which lead to cell death during seizure activity whereas the green flashes represent interventions and targets which reduce cell death during seizure activity.

\section{Conclusions and Unmet Research Needs}

We have highlighted some exciting activity in the field of metabolic and homeostatic changes during seizure activity and in epilepsy. These studies show that mitochondria are both the source and target of metabolic and homeostatic dysfunction during seizures and epilepsy. $\mathrm{Ca}^{2+}$ excess is another key candidate for these changes, but the involvement of intracellular calcium stores and particularly the ER in $\mathrm{Ca}^{2+}$ excess during seizures and epilepsy remains understudied. Moreover, mitochondrial and ER-Ca ${ }^{2+}$ stores are intimately linked with each other. How this interconnection is in seizures and epilepsy remains an open question. It is known that $\mathrm{Ca}^{2+}$ together with ROS induce 
cell death during seizure activity. We have outlined some ideas about the sources of ROS involved in this process. However, the precise sources of ROS involved remain a matter of debate. It is likely that different sources are active at different time points during seizures and epilepsy, such as has been shown in other diseases, e.g., stroke [146]. With regards to this, we think that investigations into the role of the NADPH oxidase with a focus on the different subtypes is pressing, and such investigations are ideally performed in knock out animals, since current evidence on the role of NADPH oxidase in seizures and epilepsy relies on pharmacological manipulation. This is difficult since NADPH oxidase inhibitors are rarely isoform selective and often not even NADPH oxidase specific [147]. As outlined above, NADPH oxidase isoform expression varies between different brain resident cells, thus another pertinent question is to what extent different cell types contribute to ROS formation during seizure activity. Finally, the Nrf2 pathway has been highlighted as an important pathway that is at the interface of redox and intermediary metabolism within the cell. Nrf2 activation boosts ROS scavengers, but was more recently found to have an effect on ROS producing enzymes such as the NADPH oxidase. Further characterization of this interaction will help to design ideal drug targets and allow for combinations of approaches such as have been recently advocated [143] to combat seizure induced ROS. These are one of the main events leading to cell death and continuous seizures during seizure activity and thus contribute to epilepsy and epilepsy comorbidities.

Acknowledgments: This work is supported by the Innovative Medical Research Fund (IMF, University of Münster; KO111715); the medical Faculty of the University of Münster (17-003 fellowship to SK); Cancer Research UK (C20953/A18644); the BBSRC (BB/L01923X/1); the German Research Foundation (DFG; ME 3283/5-1; GO 2505/1-1); the Iran National Science Foundation (INSF) and the German Academic Exchange Service (DAAD; 57348208). In such a short review, which is meant to highlight certain aspects in the field to outline unmet research needs, it is not possible to describe all the activity in this field and so we also apologize to those whose work is not cited here.

Author Contributions: Stjepana Kovac conceptualized and wrote the first draft for the manuscript. Ali Gorji discussed and extensively revised the manuscript. Albena T. Dinkova Kostova revised the whole manuscript with a particular focus on the section on Nrf2 and epilepsy. Alexander M. Herrmann, Nico Melzer and Sven G. Meuth all revised and contributed to the manuscript. All authors approved the final version of the manuscript.

Conflicts of Interest: The authors declare no conflict of interest.

\section{References}

1. Brodie, M.J.; Shorvon, S.D.; Canger, R.; Halász, P.; Johannessen, S.; Thompson, P.; Wieser, H.G.; Wolf, P. Commission on European Affairs: Appropriate standards of epilepsy care across Europe. Epilepsia 1997, 38, 1245-1250. [CrossRef] [PubMed]

2. Pitkänen, A.; Lukasiuk, K. Mechanisms of epileptogenesis and potential treatment targets. Lancet Neurol. 2011, 10, 173-186. [CrossRef]

3. Duncan, J.S.; Sander, J.W.; Sisodiya, S.M.; Walker, M.C. Adult epilepsy. Lancet 2006, 367, 1087-1100. [CrossRef]

4. Schapira, A.H.V. Mitochondrial diseases. Lancet 2012, 379, 1825-1834. [CrossRef]

5. Attwell, D.; Laughlin, S.B. An energy budget for signaling in the grey matter of the brain. J. Cereb. Blood Flow Metab. 2001, 21, 1133-1145. [CrossRef] [PubMed]

6. Liotta, A.; Rösner, J.; Huchzermeyer, C.; Wojtowicz, A.; Kann, O.; Schmitz, D.; Heinemann, U.; Kovács, R. Energy demand of synaptic transmission at the hippocampal Schaffer-collateral synapse. J. Cereb. Blood Flow Metab. 2012, 32, 2076-2083. [CrossRef] [PubMed]

7. Rangaraju, V.; Calloway, N.; Ryan, T.A. Activity-driven local ATP synthesis is required for synaptic function. Cell 2014, 156, 825-835. [CrossRef] [PubMed]

8. Lux, H.D.; Heinemann, U.; Dietzel, I. Ionic changes and alterations in the size of the extracellular space during epileptic activity. Adv. Neurol. 1986, 44, 619-639. [PubMed]

9. Griffiths, T.; Evans, M.C.; Meldrum, B.S. Intracellular calcium accumulation in rat hippocampus during seizures induced by bicuculline or L-allylglycine. Neuroscience 1983, 10, 385-395. [CrossRef]

10. Gilbert, M.E. The NMDA-receptor antagonist, MK-801, suppresses limbic kindling and kindled seizures. Brain Res. 1988, 463, 90-99. [CrossRef] 
11. Deshpande, L.S.; Lou, J.K.; Mian, A.; Blair, R.E.; Sombati, S.; Attkisson, E.; DeLorenzo, R.J. Time course and mechanism of hippocampal neuronal death in an in vitro model of status epilepticus: Role of NMDA receptor activation and NMDA dependent calcium entry. Eur. J. Pharmacol. 2008, 583, 73-83. [CrossRef] [PubMed]

12. Kovac, S.; Domijan, A.-M.; Walker, M.C.; Abramov, A.Y. Prolonged seizure activity impairs mitochondrial bioenergetics and induces cell death. J. Cell Sci. 2012, 125, 1796-1806. [CrossRef] [PubMed]

13. Kovac, S.; Domijan, A.-M.; Walker, M.C.; Abramov, A.Y. Seizure activity results in calcium- and mitochondria-independent ROS production via NADPH and xanthine oxidase activation. Cell Death Dis. 2014, 5, e1442. [CrossRef] [PubMed]

14. Zhu, X.; Shen, K.; Bai, Y.; Zhang, A.; Xia, Z.; Chao, J.; Yao, H. NADPH oxidase activation is required for pentylenetetrazole kindling-induced hippocampal autophagy. Free Radic. Biol. Med. 2016, 94, 230-242. [CrossRef] [PubMed]

15. Bernardi, P. Modulation of the mitochondrial cyclosporin A-sensitive permeability transition pore by the proton electrochemical gradient. Evidence that the pore can be opened by membrane depolarization. J. Biol. Chem. 1992, 267, 8834-8839. [PubMed]

16. Bernardi, P.; Petronilli, V.; Di Lisa, F.; Forte, M. A mitochondrial perspective on cell death. Trends Biochem. Sci. 2001, 26, 112-117. [CrossRef]

17. Bernardi, P.; Krauskopf, A.; Basso, E.; Petronilli, V.; Blachly-Dyson, E.; Blalchy-Dyson, E.; Di Lisa, F.; Forte, M.A. The mitochondrial permeability transition from in vitro artifact to disease target. FEBS J. 2006, 273, 2077-2099. [CrossRef] [PubMed]

18. Zsurka, G.; Kunz, W.S. Mitochondrial dysfunction and seizures: The neuronal energy crisis. Lancet Neurol. 2015, 14, 956-966. [CrossRef]

19. Sander, J.W. Some aspects of prognosis in the epilepsies: A review. Epilepsia 1993, 34, 1007-1016. [CrossRef] [PubMed]

20. Altmann, R. Die Elementarorganismen Und Ihre Beziehungen Zu Den Zellen; Veit \& Comp.: Leipzig, Germany, 1890.

21. Chance, B. Spectra and reaction kinetics of respiratory pigments of homogenized and intact cells. Nature 1952, 169, 215-221. [CrossRef] [PubMed]

22. Chance, B.; Williams, G.R. Respiratory enzymes in oxidative phosphorylation. IV. The respiratory chain. J. Biol. Chem. 1955, 217, 429-438. [PubMed]

23. Chance, B.; Williams, G.R. Respiratory enzymes in oxidative phosphorylation. II. Difference spectra. J. Biol. Chem. 1955, 217, 395-407. [PubMed]

24. Ernster, L.; Schatz, G. Mitochondria: A historical review. J. Cell Biol. 1981, 91, 227s-255s. [CrossRef] [PubMed]

25. Mitchell, P. Coupling of phosphorylation to electron and hydrogen transfer by a chemi-osmotic type of mechanism. Nature 1961, 191, 144-148. [CrossRef] [PubMed]

26. Almeida, A.; Almeida, J.; Bolaños, J.P.; Moncada, S. Different responses of astrocytes and neurons to nitric oxide: The role of glycolytically generated ATP in astrocyte protection. Proc. Natl. Acad. Sci. USA 2001, 98, 15294-15299. [CrossRef] [PubMed]

27. Szabadkai, G.; Duchen, M.R. Mitochondria: The hub of cellular Ca ${ }^{2+}$ signaling. Physiology 2008, $23,84-94$. [CrossRef] [PubMed]

28. Ugarte-Uribe, B.; García-Sáez, A.J. Apoptotic foci at mitochondria: In and around Bax pores. Philos. Trans. R. Soc. Lond. Ser. B Biol. Sci. 2017, 372, 20160217. [CrossRef] [PubMed]

29. King, L.J.; Lowry, O.H.; Passonneau, J.V.; Venson, V. Effects of convulsants on energy reserves in the cerebral cortex. J. Neurochem. 1967, 14, 599-611. [CrossRef] [PubMed]

30. Sacktor, B.; Wilson, J.E.; Tiekert, C.G. Regulation of glycolysis in brain, in situ, during convulsions. J. Biol. Chem. 1966, 241, 5071-5075. [PubMed]

31. Sanders, A.P.; Kramer, R.S.; Woodhall, B.; Currie, W.D. Brain adenosine triphosphate: Decreased concentration precedes convulsions. Science 1970, 169, 206-208. [CrossRef] [PubMed]

32. Kovac, S.; Abramov, A.Y.; Walker, M.C. Energy depletion in seizures: Anaplerosis as a strategy for future therapies. Neuropharmacology 2013, 69, 96-104. [CrossRef] [PubMed]

33. Bough, K.J.; Wetherington, J.; Hassel, B.; Pare, J.F.; Gawryluk, J.W.; Greene, J.G.; Shaw, R.; Smith, Y.; Geiger, J.D.; Dingledine, R.J. Mitochondrial biogenesis in the anticonvulsant mechanism of the ketogenic diet. Ann. Neurol. 2006, 60, 223-235. [CrossRef] [PubMed] 
34. Bough, K. Energy metabolism as part of the anticonvulsant mechanism of the ketogenic diet. Epilepsia 2008, 49 (Suppl. S8), 91-93. [CrossRef] [PubMed]

35. Greco, T.; Glenn, T.C.; Hovda, D.A.; Prins, M.L. Ketogenic diet decreases oxidative stress and improves mitochondrial respiratory complex activity. J. Cereb. Blood Flow Metab. 2016, 36, 1603-1613. [CrossRef] [PubMed]

36. Rho, J.M. How does the ketogenic diet induce anti-seizure effects? Neurosci. Lett. 2017, 637, 4-10. [CrossRef] [PubMed]

37. Pasca, L.; De Giorgis, V.; Macasaet, J.A.; Trentani, C.; Tagliabue, A.; Veggiotti, P. The changing face of dietary therapy for epilepsy. Eur. J. Pediatr. 2016, 175, 1267-1276. [CrossRef] [PubMed]

38. Dressler, A.; Trimmel-Schwahofer, P.; Reithofer, E.; Mühlebner, A.; Gröppel, G.; Reiter-Fink, E.; Benninger, F.; Grassl, R.; Feucht, M. Efficacy and tolerability of the ketogenic diet in Dravet syndrome-Comparison with various standard antiepileptic drug regimen. Epilepsy Res. 2015, 109, 81-89. [CrossRef] [PubMed]

39. Paleologou, E.; Ismayilova, N.; Kinali, M. Use of the Ketogenic Diet to Treat Intractable Epilepsy in Mitochondrial Disorders. J. Clin. Med. 2017, 6, E56. [CrossRef] [PubMed]

40. Griffiths, T.; Evans, M.C.; Meldrum, B.S. Intracellular sites of early calcium accumulation in the rat hippocampus during status epilepticus. Neurosci. Lett. 1982, 30, 329-334. [CrossRef]

41. De Stefani, D.; Raffaello, A.; Teardo, E.; Szabò, I.; Rizzuto, R. A forty-kilodalton protein of the inner membrane is the mitochondrial calcium uniporter. Nature 2011, 476, 336-340. [CrossRef] [PubMed]

42. Nicholls, D.G.; Chalmers, S. The integration of mitochondrial calcium transport and storage. J. Bioenerg. Biomembr. 2004, 36, 277-281. [CrossRef] [PubMed]

43. Wang, C.; Xie, N.; Wang, Y.; Li, Y.; Ge, X.; Wang, M. Role of the Mitochondrial Calcium Uniporter in Rat Hippocampal Neuronal Death after Pilocarpine-Induced Status Epilepticus. Neurochem. Res. 2015, 40, 1739-1746. [CrossRef] [PubMed]

44. Nicholls, D.G.; Budd, S.L. Mitochondria and neuronal survival. Physiol. Rev. 2000, 80, 315-360. [PubMed]

45. Giorgio, V.; von Stockum, S.; Antoniel, M.; Fabbro, A.; Fogolari, F.; Forte, M.; Glick, G.D.; Petronilli, V.; Zoratti, M.; Szabó, I.; et al. Dimers of mitochondrial ATP synthase form the permeability transition pore. Proc. Natl. Acad. Sci. USA 2013, 110, 5887-5892. [CrossRef] [PubMed]

46. Bernardi, P.; Rasola, A.; Forte, M.; Lippe, G. The Mitochondrial Permeability Transition Pore: Channel Formation by F-ATP Synthase, Integration in Signal Transduction, and Role in Pathophysiology. Physiol. Rev. 2015, 95, 1111-1155. [CrossRef] [PubMed]

47. Kim, D.Y.; Simeone, K.A.; Simeone, T.A.; Pandya, J.D.; Wilke, J.C.; Ahn, Y.; Geddes, J.W.; Sullivan, P.G.; Rho, J.M. Ketone bodies mediate antiseizure effects through mitochondrial permeability transition. Ann. Neurol. 2015, 78, 77-87. [CrossRef] [PubMed]

48. Meldrum, B.S.; Vigouroux, R.A.; Brierley, J.B. Systemic factors and epileptic brain damage. Prolonged seizures in paralyzed, artificially ventilated baboons. Arch. Neurol. 1973, 29, 82-87. [CrossRef] [PubMed]

49. Schmutzhard, E.; Pfausler, B. Complications of the management of status epilepticus in the intensive care unit. Epilepsia 2011, 52 (Suppl. S8), 39-41. [CrossRef] [PubMed]

50. Norwood, B.A.; Bauer, S.; Wegner, S.; Hamer, H.M.; Oertel, W.H.; Sloviter, R.S.; Rosenow, F. Electrical stimulation-induced seizures in rats: A "dose-response" study on resultant neurodegeneration. Epilepsia 2011, 52, e109-e112. [CrossRef] [PubMed]

51. D'Orsi, B.; Mateyka, J.; Prehn, J.H.M. Control of mitochondrial physiology and cell death by the Bcl-2 family proteins Bax and Bok. Neurochem. Int. 2017, in press.

52. Nobili, P.; Colciaghi, F.; Finardi, A.; Zambon, S.; Locatelli, D.; Battaglia, G.S. Continuous neurodegeneration and death pathway activation in neurons and glia in an experimental model of severe chronic epilepsy. Neurobiol. Dis. 2015, 83, 54-66. [CrossRef] [PubMed]

53. Shalini, S.; Dorstyn, L.; Dawar, S.; Kumar, S. Old, new and emerging functions of caspases. Cell Death Differ. 2015, 22, 526-539. [CrossRef] [PubMed]

54. Henshall, D.C.; Murphy, B.M. Modulators of neuronal cell death in epilepsy. Curr. Opin. Pharmacol. 2008, 8, 75-81. [CrossRef] [PubMed]

55. Henshall, D.C.; Araki, T.; Schindler, C.K.; Lan, J.-Q.; Tiekoter, K.L.; Taki, W.; Simon, R.P. Activation of Bcl-2-Associated Death Protein and Counter-Response of Akt within Cell Populations during Seizure-Induced Neuronal Death. J. Neurosci. 2002, 22, 8458-8465. [PubMed] 
56. Henshall, D.C.; Chen, J.; Simon, R.P. Involvement of caspase-3-like protease in the mechanism of cell death following focally evoked limbic seizures. J. Neurochem. 2000, 74, 1215-1223. [CrossRef] [PubMed]

57. Barel, O.; Christine V Malicdan, M.; Ben-Zeev, B.; Kandel, J.; Pri-Chen, H.; Stephen, J.; Castro, I.G.; Metz, J.; Atawa, O.; Moshkovitz, S.; et al. Deleterious variants in TRAK1 disrupt mitochondrial movement and cause fatal encephalopathy. Brain 2017, 140, 568-581. [CrossRef] [PubMed]

58. Heilbrunn, L.V. An Outline of General Physiology, 3rd ed.; W. B. Saunders: Philadelphia, PA, USA, 1952.

59. Heilbrunn, L.V.; Wiercinski, F.J. The action of various cations on muscle protoplasm. J. Cell. Physiol. 1947, 29, 15-32. [CrossRef]

60. Streb, H.; Irvine, R.F.; Berridge, M.J.; Schulz, I. Release of $\mathrm{Ca}^{2+}$ from a nonmitochondrial intracellular store in pancreatic acinar cells by inositol-1,4,5-trisphosphate. Nature 1983, 306, 67-69. [CrossRef] [PubMed]

61. Verkhratsky, A. Physiology and Pathophysiology of the Calcium Store in the Endoplasmic Reticulum of Neurons. Physiol. Rev. 2005, 85, 201-279. [CrossRef] [PubMed]

62. Sokal, D.M.; Mason, R.; Parker, T.L. Multi-neuronal recordings reveal a differential effect of thapsigargin on bicuculline- or gabazine-induced epileptiform excitability in rat hippocampal neuronal networks. Neuropharmacology 2000, 39, 2408-2417. [CrossRef]

63. Rutecki, P.A.; Sayin, U.; Yang, Y.; Hadar, E. Determinants of ictal epileptiform patterns in the hippocampal slice. Epilepsia 2002, 43 (Suppl. S5), 179-183. [CrossRef] [PubMed]

64. Mikami, Y.; Kanemaru, K.; Okubo, Y.; Nakaune, T.; Suzuki, J.; Shibata, K.; Sugiyama, H.; Koyama, R.; Murayama, T.; Ito, A.; et al. Nitric Oxide-induced Activation of the Type 1 Ryanodine Receptor Is Critical for Epileptic Seizure-induced Neuronal Cell Death. EBioMedicine 2016, 11, 253-261. [CrossRef] [PubMed]

65. Dingledine, R.; Borges, K.; Bowie, D.; Traynelis, S.F. The glutamate receptor ion channels. Pharmacol. Rev. 1999, 51, 7-61. [PubMed]

66. Ormandy, G.C.; Jope, R.S.; Snead, O.C. Anticonvulsant actions of MK-801 on the lithium-pilocarpine model of status epilepticus in rats. Exp. Neurol. 1989, 106, 172-180. [CrossRef]

67. Fujikawa, D.G.; Daniels, A.H.; Kim, J.S. The competitive NMDA receptor antagonist CGP 40116 protects against status epilepticus-induced neuronal damage. Epilepsy Res. 1994, 17, 207-219. [CrossRef]

68. Finardi, A.; Colciaghi, F.; Castana, L.; Locatelli, D.; Marras, C.E.; Nobili, P.; Fratelli, M.; Bramerio, M.A.; Lorusso, G.; Battaglia, G.S. Long-duration epilepsy affects cell morphology and glutamatergic synapses in type IIB focal cortical dysplasia. Acta Neuropathol. 2013, 126, 219-235. [CrossRef] [PubMed]

69. Battaglia, G.; Colciaghi, F.; Finardi, A.; Nobili, P. Intrinsic epileptogenicity of dysplastic cortex: Converging data from experimental models and human patients. Epilepsia 2013, 54 (Suppl. S6), 33-36. [CrossRef] [PubMed]

70. Dalmau, J.; Tüzün, E.; Wu, H.; Masjuan, J.; Rossi, J.E.; Voloschin, A.; Baehring, J.M.; Shimazaki, H.; Koide, R.; King, D.; et al. Paraneoplastic anti- $N$-methyl-D-aspartate receptor encephalitis associated with ovarian teratoma. Ann. Neurol. 2007, 61, 25-36. [CrossRef] [PubMed]

71. Dalmau, J.; Gleichman, A.J.; Hughes, E.G.; Rossi, J.E.; Peng, X.; Lai, M.; Dessain, S.K.; Rosenfeld, M.R.; Balice-Gordon, R.; Lynch, D.R. Anti-NMDA-receptor encephalitis: Case series and analysis of the effects of antibodies. Lancet Neurol. 2008, 7, 1091-1098. [CrossRef]

72. Bien, C.G.; Vincent, A.; Barnett, M.H.; Becker, A.J.; Blümcke, I.; Graus, F.; Jellinger, K.A.; Reuss, D.E.; Ribalta, T.; Schlegel, J.; et al. Immunopathology of autoantibody-associated encephalitides: Clues for pathogenesis. Brain 2012, 135, 1622-1638. [CrossRef] [PubMed]

73. Camdessanché, J.-P.; Streichenberger, N.; Cavillon, G.; Rogemond, V.; Jousserand, G.; Honnorat, J.; Convers, P.; Antoine, J.-C. Brain immunohistopathological study in a patient with anti-NMDAR encephalitis. Eur. J. Neurol. 2011, 18, 929-931. [CrossRef] [PubMed]

74. Tüzün, E.; Zhou, L.; Baehring, J.M.; Bannykh, S.; Rosenfeld, M.R.; Dalmau, J. Evidence for antibody-mediated pathogenesis in anti-NMDAR encephalitis associated with ovarian teratoma. Acta Neuropathol. 2009, 118, 737-743. [CrossRef] [PubMed]

75. Epi4K Consortium; Epilepsy Phenome/Genome Project; Allen, A.S.; Berkovic, S.F.; Cossette, P.; Delanty, N.; Dlugos, D.; Eichler, E.E.; Epstein, M.P.; Glauser, T.; et al. De novo mutations in epileptic encephalopathies. Nature 2013, 501, 217-221. [CrossRef] [PubMed]

76. Ohba, C.; Shiina, M.; Tohyama, J.; Haginoya, K.; Lerman-Sagie, T.; Okamoto, N.; Blumkin, L.; Lev, D.; Mukaida, S.; Nozaki, F.; et al. GRIN1 mutations cause encephalopathy with infantile-onset epilepsy, and hyperkinetic and stereotyped movement disorders. Epilepsia 2015, 56, 841-848. [CrossRef] [PubMed] 
77. Duncan, G.E.; Inada, K.; Koller, B.H.; Moy, S.S. Increased sensitivity to kainic acid in a genetic model of reduced NMDA receptor function. Brain Res. 2010, 1307, 166-176. [CrossRef] [PubMed]

78. Gorji, A.; Speckmann, E.J. Low concentration of DL-2-amino-5-phosphonovalerate induces epileptiform activity in guinea pig hippocampal slices. Epilepsia 2001, 42, 1228-1230. [CrossRef] [PubMed]

79. Rajasekaran, K.; Todorovic, M.; Kapur, J. Calcium-permeable AMPA receptors are expressed in a rodent model of status epilepticus. Ann. Neurol. 2012, 72, 91-102. [CrossRef] [PubMed]

80. Khosravani, H.; Zamponi, G.W. Voltage-Gated Calcium Channels and Idiopathic Generalized Epilepsies. Physiol. Rev. 2006, 86, 941-966. [CrossRef] [PubMed]

81. Cain, S.M.; Snutch, T.P. Voltage-Gated Calcium Channels in Epilepsy. In Jasper's Basic Mechanisms of the Epilepsies; Noebels, J.L., Avoli, M., Rogawski, M.A., Olsen, R.W., Delgado-Escueta, A.V., Eds.; National Center for Biotechnology Information (US): Bethesda, MD, USA, 2012.

82. Van Loo, K.M.J.; Schaub, C.; Pitsch, J.; Kulbida, R.; Opitz, T.; Ekstein, D.; Dalal, A.; Urbach, H.; Beck, H.; Yaari, Y.; et al. Zinc regulates a key transcriptional pathway for epileptogenesis via metal-regulatory transcription factor 1. Nat. Commun. 2015, 6, 8688. [CrossRef] [PubMed]

83. Becker, A.J.; Pitsch, J.; Sochivko, D.; Opitz, T.; Staniek, M.; Chen, C.-C.; Campbell, K.P.; Schoch, S.; Yaari, Y.; Beck, H. Transcriptional upregulation of Cav3.2 mediates epileptogenesis in the pilocarpine model of epilepsy. J. Neurosci. 2008, 28, 13341-13353. [CrossRef] [PubMed]

84. Naziroğlu, M.; Kutluhan, S.; Yilmaz, M. Selenium and topiramate modulates brain microsomal oxidative stress values, $\mathrm{Ca}^{2+}$-ATPase activity, and EEG records in pentylentetrazol-induced seizures in rats. J. Membr. Biol. 2008, 225, 39-49. [CrossRef] [PubMed]

85. Ketelaars, S.O.M.; Gorter, J.A.; Aronica, E.; Wadman, W.J. Calcium extrusion protein expression in the hippocampal formation of chronic epileptic rats after kainate-induced status epilepticus. Epilepsia 2004, 45, 1189-1201. [CrossRef] [PubMed]

86. Garcia, M.L.; Murray, K.D.; Garcia, V.B.; Strehler, E.E.; Isackson, P.J. Seizure-induced alterations of plasma membrane calcium ATPase isoforms 1, 2 and 3 mRNA and protein in rat hippocampus. Brain Res. Mol. Brain Res. 1997, 45, 230-238. [CrossRef]

87. Abramov, A.Y.; Canevari, L.; Duchen, M.R. Beta-amyloid peptides induce mitochondrial dysfunction and oxidative stress in astrocytes and death of neurons through activation of NADPH oxidase. J. Neurosci. 2004, 24, 565-575. [CrossRef] [PubMed]

88. Gandhi, S.; Wood-Kaczmar, A.; Yao, Z.; Plun-Favreau, H.; Deas, E.; Klupsch, K.; Downward, J.; Latchman, D.S.; Tabrizi, S.J.; Wood, N.W.; et al. PINK1-associated Parkinson's disease is caused by neuronal vulnerability to calcium-induced cell death. Mol. Cell 2009, 33, 627-638. [CrossRef] [PubMed]

89. Halliwell, B. Oxidative stress and neurodegeneration: Where are we now? J. Neurochem. 2006, 97, $1634-1658$. [CrossRef] [PubMed]

90. Malinska, D.; Kulawiak, B.; Kudin, A.P.; Kovacs, R.; Huchzermeyer, C.; Kann, O.; Szewczyk, A.; Kunz, W.S. Complex III-dependent superoxide production of brain mitochondria contributes to seizure-related ROS formation. Biochim. Biophys. Acta 2010, 1797, 1163-1170. [CrossRef] [PubMed]

91. Pestana, R.R.F.; Kinjo, E.R.; Hernandes, M.S.; Britto, L.R.G. Reactive oxygen species generated by NADPH oxidase are involved in neurodegeneration in the pilocarpine model of temporal lobe epilepsy. Neurosci. Lett. 2010, 484, 187-191. [CrossRef] [PubMed]

92. Dröge, W. Free Radicals in the Physiological Control of Cell Function. Physiol. Rev. 2002, 82, 47-95. [CrossRef] [PubMed]

93. Heeres, J.T.; Hergenrother, P.J. Poly(ADP-ribose) makes a date with death. Curr. Opin. Chem. Biol. 2007, 11, 644-653. [CrossRef] [PubMed]

94. Lai, Y.-C.; Baker, J.S.; Donti, T.; Graham, B.H.; Craigen, W.J.; Anderson, A.E. Mitochondrial Dysfunction Mediated by Poly(ADP-Ribose) Polymerase-1 Activation Contributes to Hippocampal Neuronal Damage Following Status Epilepticus. Int. J. Mol. Sci. 2017, 18, E1502. [CrossRef] [PubMed]

95. Gutteridge, J.M.C.; Halliwell, B. The measurement and mechanism of lipid peroxidation in biological systems. Trends Biochem. Sci. 1990, 15, 129-135. [CrossRef]

96. Kovac, S.; Dinkova-Kostova, A.T.; Abramov, A.Y. The Role of Reactive Oxygen Species in Epilepsy. React. Oxyg. Species 2016, 1, 38-52. [CrossRef]

97. Bruce, A.J.; Baudry, M. Oxygen free radicals in rat limbic structures after kainate-induced seizures. Free Radic. Biol. Med. 1995, 18, 993-1002. [CrossRef] 
98. Kovács, R.; Schuchmann, S.; Gabriel, S.; Kann, O.; Kardos, J.; Heinemann, U. Free radical-mediated cell damage after experimental status epilepticus in hippocampal slice cultures. J. Neurophysiol. 2002, 88, 2909-2918. [CrossRef] [PubMed]

99. Delanty, N.; Dichter, D.M. Antioxidant therapy in neurologic disease. Arch. Neurol. 2000, 57, 1265-1270. [CrossRef] [PubMed]

100. Volmering, E.; Niehusmann, P.; Peeva, V.; Grote, A.; Zsurka, G.; Altmüller, J.; Nürnberg, P.; Becker, A.J.; Schoch, S.; Elger, C.E.; et al. Neuropathological signs of inflammation correlate with mitochondrial DNA deletions in mesial temporal lobe epilepsy. Acta Neuropathol. 2016, 132, 277-288. [CrossRef] [PubMed]

101. Royer-Pokora, B.; Kunkel, L.M.; Monaco, A.P.; Goff, S.C.; Newburger, P.E.; Baehner, R.L.; Cole, F.S.; Curnutte, J.T.; Orkin, S.H. Cloning the gene for an inherited human disorder-Chronic granulomatous disease-On the basis of its chromosomal location. Nature 1986, 322, 32-38. [CrossRef] [PubMed]

102. Kleinschnitz, C.; Grund, H.; Wingler, K.; Armitage, M.E.; Jones, E.; Mittal, M.; Barit, D.; Schwarz, T.; Geis, C.; Kraft, P.; et al. Post-stroke inhibition of induced NADPH oxidase type 4 prevents oxidative stress and neurodegeneration. PLoS Biol. 2010, 8, e1000479. [CrossRef] [PubMed]

103. Bedard, K.; Krause, K.-H. The NOX family of ROS-generating NADPH oxidases: Physiology and pathophysiology. Physiol. Rev. 2007, 87, 245-313. [CrossRef] [PubMed]

104. Nayernia, Z.; Jaquet, V.; Krause, K.-H. New insights on NOX enzymes in the central nervous system. Antioxid. Redox Signal. 2014, 20, 2815-2837. [CrossRef] [PubMed]

105. Olguín-Albuerne, M.; Domínguez, G.; Morán, J. Effect of staurosporine in the morphology and viability of cerebellar astrocytes: Role of reactive oxygen species and NADPH oxidase. Oxidative Med. Cell. Longev. 2014, 2014, 678371. [CrossRef] [PubMed]

106. Hohn, D.C.; Lehrer, R.I. NADPH oxidase deficiency in X-linked chronic granulomatous disease. J. Clin. Investig. 1975, 55, 707-713. [CrossRef] [PubMed]

107. Fischer, M.T.; Sharma, R.; Lim, J.L.; Haider, L.; Frischer, J.M.; Drexhage, J.; Mahad, D.; Bradl, M.; van Horssen, J.; Lassmann, H. NADPH oxidase expression in active multiple sclerosis lesions in relation to oxidative tissue damage and mitochondrial injury. Brain 2012, 135, 886-899. [CrossRef] [PubMed]

108. Kuroda, J.; Ago, T.; Nishimura, A.; Nakamura, K.; Matsuo, R.; Wakisaka, Y.; Kamouchi, M.; Kitazono, T. Nox4 is a major source of superoxide production in human brain pericytes. J. Vasc. Res. 2014, 51, 429-438. [CrossRef] [PubMed]

109. Sirokmány, G.; Donkó, Á.; Geiszt, M. Nox/Duox Family of NADPH Oxidases: Lessons from Knockout Mouse Models. Trends Pharmacol. Sci. 2016, 37, 318-327. [CrossRef] [PubMed]

110. Brennan, A.M.; Suh, S.W.; Won, S.J.; Narasimhan, P.; Kauppinen, T.M.; Lee, H.; Edling, Y.; Chan, P.H.; Swanson, R.A. NADPH oxidase is the primary source of superoxide induced by NMDA receptor activation. Nat. Neurosci. 2009, 12, 857-863. [CrossRef] [PubMed]

111. Girouard, H.; Wang, G.; Gallo, E.F.; Anrather, J.; Zhou, P.; Pickel, V.M.; Iadecola, C. NMDA receptor activation increases free radical production through nitric oxide and NOX2. J. Neurosci. 2009, 29, 2545-2552. [CrossRef] [PubMed]

112. Kim, J.H.; Jang, B.G.; Choi, B.Y.; Kim, H.S.; Sohn, M.; Chung, T.N.; Choi, H.C.; Song, H.K.; Suh, S.W. Post-treatment of an NADPH oxidase inhibitor prevents seizure-induced neuronal death. Brain Res. 2013, 1499, 163-172. [CrossRef] [PubMed]

113. Patel, M.; Li, Q.-Y.; Chang, L.-Y.; Crapo, J.; Liang, L.-P. Activation of NADPH oxidase and extracellular superoxide production in seizure-induced hippocampal damage. J. Neurochem. 2005, 92, 123-131. [CrossRef] [PubMed]

114. Di Maio, R.; Mastroberardino, P.G.; Hu, X.; Montero, L.; Greenamyre, J.T. Pilocapine alters NMDA receptor expression and function in hippocampal neurons: NADPH oxidase and ERK1/2 mechanisms. Neurobiol. Dis. 2011, 42, 482-495. [CrossRef] [PubMed]

115. Tsai, C.-Y.; Chan, J.Y.H.; Hsu, K.; Chang, A.Y.W.; Chan, S.H.H. Brain-Derived Neurotrophic Factor Ameliorates Brain Stem Cardiovascular Dysregulation during Experimental Temporal Lobe Status Epilepticus. PLoS ONE 2012, 7, e33527. [CrossRef] [PubMed]

116. Kim, J.-E.; Ryu, H.J.; Kang, T.-C. Status epilepticus induces vasogenic edema via tumor necrosis factor- $\alpha /$ endothelin-1-mediated two different pathways. PLOS ONE 2013, 8, e74458. [CrossRef] [PubMed] 
117. Pecorelli, A.; Natrella, F.; Belmonte, G.; Miracco, C.; Cervellati, F.; Ciccoli, L.; Mariottini, A.; Rocchi, R.; Vatti, G.; Bua, A.; et al. NADPH oxidase activation and 4-hydroxy-2-nonenal/aquaporin-4 adducts as possible new players in oxidative neuronal damage presents in drug-resistant epilepsy. Biochim. Biophys. Acta 2015, 1852, 507-519. [CrossRef] [PubMed]

118. Williams, S.; Hamil, N.; Abramov, A.Y.; Walker, M.C.; Kovac, S. Status epilepticus results in persistent overproduction of reactive oxygen species, inhibition of which is neuroprotective. Neuroscience 2015, 303, 160-165. [CrossRef] [PubMed]

119. Case, A.J.; Li, S.; Basu, U.; Tian, J.; Zimmerman, M.C. Mitochondrial-localized NADPH oxidase 4 is a source of superoxide in angiotensin II-stimulated neurons. Am. J. Physiol. Heart Circ. Physiol. 2013, 305, H19-H28. [CrossRef] [PubMed]

120. Kozieł, R.; Pircher, H.; Kratochwil, M.; Lener, B.; Hermann, M.; Dencher, N.A.; Jansen-Dürr, P. Mitochondrial respiratory chain complex I is inactivated by NADPH oxidase Nox4. Biochem. J. 2013, 452, 231-239. [CrossRef] [PubMed]

121. Ueda, Y.; Yokoyama, H.; Niwa, R.; Konaka, R.; Ohya-Nishiguchi, H.; Kamada, H. Generation of lipid radicals in the hippocampal extracellular space during kainic acid-induced seizures in rats. Epilepsy Res. 1997, 26, 329-333. [CrossRef]

122. Baran, H.; Vass, K.; Lassmann, H.; Hornykiewicz, O. The cyclooxygenase and lipoxygenase inhibitor BW755C protects rats against kainic acid-induced seizures and neurotoxicity. Brain Res. 1994, 646, 201-206. [CrossRef]

123. Hayes, J.D.; Dinkova-Kostova, A.T. The Nrf2 regulatory network provides an interface between redox and intermediary metabolism. Trends Biochem. Sci. 2014, 39, 199-218. [CrossRef] [PubMed]

124. Holmström, K.M.; Baird, L.; Zhang, Y.; Hargreaves, I.; Chalasani, A.; Land, J.M.; Stanyer, L.; Yamamoto, M.; Dinkova-Kostova, A.T.; Abramov, A.Y. Nrf2 impacts cellular bioenergetics by controlling substrate availability for mitochondrial respiration. Biol. Open 2013, 2, 761-770. [CrossRef] [PubMed]

125. Holmström, K.M.; Kostov, R.V.; Dinkova-Kostova, A.T. The multifaceted role of Nrf2 in mitochondrial function. Curr. Opin. Toxicol. 2016, 1, 80-91. [CrossRef] [PubMed]

126. Dinkova-Kostova, A.T.; Baird, L.; Holmström, K.M.; Meyer, C.J.; Abramov, A.Y. The spatiotemporal regulation of the Keap1-Nrf2 pathway and its importance in cellular bioenergetics. Biochem. Soc. Trans. 2015, 43, 602-610. [CrossRef] [PubMed]

127. Cullinan, S.B.; Gordan, J.D.; Jin, J.; Harper, J.W.; Diehl, J.A. The Keap1-BTB protein is an adaptor that bridges Nrf2 to a Cul3-based E3 ligase: Oxidative stress sensing by a Cul3-Keap1 ligase. Mol. Cell. Biol. 2004, 24, 8477-8486. [CrossRef] [PubMed]

128. Kobayashi, A.; Kang, M.-I.; Okawa, H.; Ohtsuji, M.; Zenke, Y.; Chiba, T.; Igarashi, K.; Yamamoto, M. Oxidative stress sensor Keap1 functions as an adaptor for Cul3-based E3 ligase to regulate proteasomal degradation of Nrf2. Mol. Cell. Biol. 2004, 24, 7130-7139. [CrossRef] [PubMed]

129. Zhang, D.D.; Lo, S.-C.; Cross, J.V.; Templeton, D.J.; Hannink, M. Keap1 is a redox-regulated substrate adaptor protein for a Cul3-dependent ubiquitin ligase complex. Mol. Cell. Biol. 2004, 24, 10941-10953. [CrossRef] [PubMed]

130. Dinkova-Kostova, A.T.; Holtzclaw, W.D.; Cole, R.N.; Itoh, K.; Wakabayashi, N.; Katoh, Y.; Yamamoto, M.; Talalay, P. Direct evidence that sulfhydryl groups of Keap1 are the sensors regulating induction of phase 2 enzymes that protect against carcinogens and oxidants. Proc. Natl. Acad. Sci. USA 2002, 99, 11908-11913. [CrossRef] [PubMed]

131. McMahon, M.; Lamont, D.J.; Beattie, K.A.; Hayes, J.D. Keap1 perceives stress via three sensors for the endogenous signaling molecules nitric oxide, zinc, and alkenals. Proc. Natl. Acad. Sci. USA 2010, 107, 18838-18843. [CrossRef] [PubMed]

132. Hu, L.; Magesh, S.; Chen, L.; Wang, L.; Lewis, T.A.; Chen, Y.; Khodier, C.; Inoyama, D.; Beamer, L.J.; Emge, T.J.; et al. Discovery of a small-molecule inhibitor and cellular probe of Keap1-Nrf2 protein-protein interaction. Bioorg. Med. Chem. Lett. 2013, 23, 3039-3043. [CrossRef] [PubMed]

133. Marcotte, D.; Zeng, W.; Hus, J.-C.; McKenzie, A.; Hession, C.; Jin, P.; Bergeron, C.; Lugovskoy, A.; Enyedy, I.; Cuervo, H.; et al. Small molecules inhibit the interaction of Nrf2 and the Keap1 Kelch domain through a non-covalent mechanism. Bioorg. Med. Chem. 2013, 21, 4011-4019. [CrossRef] [PubMed]

134. Fox, R.J.; Kita, M.; Cohan, S.L.; Henson, L.J.; Zambrano, J.; Scannevin, R.H.; O'Gorman, J.; Novas, M.; Dawson, K.T.; Phillips, J.T. BG-12 (dimethyl fumarate): A review of mechanism of action, efficacy, and safety. Curr. Med. Res. Opin. 2014, 30, 251-262. [CrossRef] [PubMed] 
135. Wild, A.C.; Moinova, H.R.; Mulcahy, R.T. Regulation of $\gamma$-glutamylcysteine synthetase subunit gene expression by the transcription factor Nrf2. J. Biol. Chem. 1999, 274, 33627-33636. [CrossRef] [PubMed]

136. Sasaki, H.; Sato, H.; Kuriyama-Matsumura, K.; Sato, K.; Maebara, K.; Wang, H.; Tamba, M.; Itoh, K.; Yamamoto, M.; Bannai, S. Electrophile response element-mediated induction of the cystine/glutamate exchange transporter gene expression. J. Biol. Chem. 2002, 277, 44765-44771. [CrossRef] [PubMed]

137. Greco, T.; Shafer, J.; Fiskum, G. Sulforaphane inhibits mitochondrial permeability transition and oxidative stress. Free Radic. Biol. Med. 2011, 51, 2164-2171. [CrossRef] [PubMed]

138. Kovac, S.; Angelova, P.R.; Holmström, K.M.; Zhang, Y.; Dinkova-Kostova, A.T.; Abramov, A.Y. Nrf2 regulates ROS production by mitochondria and NADPH oxidase. Biochim. Biophys. Acta 2015, 1850, 794-801. [CrossRef] [PubMed]

139. Carmona-Aparicio, L.; Pérez-Cruz, C.; Zavala-Tecuapetla, C.; Granados-Rojas, L.; Rivera-Espinosa, L.; Montesinos-Correa, H.; Hernández-Damián, J.; Pedraza-Chaverri, J.; Sampieri, A.; Coballase-Urrutia, E.; et al. Overview of Nrf2 as Therapeutic Target in Epilepsy. Int. J. Mol. Sci. 2015, 16, 18348-18367. [CrossRef] [PubMed]

140. Mazzuferi, M.; Kumar, G.; van Eyll, J.; Danis, B.; Foerch, P.; Kaminski, R.M. Nrf2 defense pathway: Experimental evidence for its protective role in epilepsy. Ann. Neurol. 2013, 74, 560-568. [CrossRef] [PubMed]

141. Carrasco-Pozo, C.; Tan, K.N.; Borges, K. Sulforaphane is anticonvulsant and improves mitochondrial function. J. Neurochem. 2015, 135, 932-942. [CrossRef] [PubMed]

142. Wang, W.; Wu, Y.; Zhang, G.; Fang, H.; Wang, H.; Zang, H.; Xie, T.; Wang, W. Activation of Nrf2-ARE signal pathway protects the brain from damage induced by epileptic seizure. Brain Res. 2014, 1544, 54-61. [CrossRef] [PubMed]

143. Pauletti, A.; Terrone, G.; Shekh-Ahmad, T.; Salamone, A.; Ravizza, T.; Rizzi, M.; Pastore, A.; Pascente, R.; Liang, L.-P.; Villa, B.R.; et al. Targeting oxidative stress improves disease outcomes in a rat model of acquired epilepsy. Brain 2017, 140, 1885-1899. [CrossRef] [PubMed]

144. Socała, K.; Nieoczym, D.; Kowalczuk-Vasilev, E.; Wyska, E.; Wlaź, P. Increased seizure susceptibility and other toxicity symptoms following acute sulforaphane treatment in mice. Toxicol. Appl. Pharmacol. 2017, 326, 43-53. [CrossRef] [PubMed]

145. Williamson, T.P.; Amirahmadi, S.; Joshi, G.; Kaludov, N.K.; Martinov, M.N.; Johnson, D.A.; Johnson, J.A. Discovery of potent, novel Nrf2 inducers via quantum modeling, virtual screening and in vitro experimental validation. Chem. Biol. Drug Des. 2012, 80, 810-820. [CrossRef] [PubMed]

146. Abramov, A.Y.; Scorziello, A.; Duchen, M.R. Three distinct mechanisms generate oxygen free radicals in neurons and contribute to cell death during anoxia and reoxygenation. J. Neurosci. 2007, 27, 1129-1138. [CrossRef] [PubMed]

147. Altenhöfer, S.; Radermacher, K.A.; Kleikers, P.W.M.; Wingler, K.; Schmidt, H.H.H.W. Evolution of NADPH Oxidase Inhibitors: Selectivity and Mechanisms for Target Engagement. Antioxid. Redox Signal. 2015, 23, 406-427. [CrossRef] [PubMed]

(C) 2017 by the authors. Licensee MDPI, Basel, Switzerland. This article is an open access article distributed under the terms and conditions of the Creative Commons Attribution (CC BY) license (http://creativecommons.org/licenses/by/4.0/). 